[DOI: 10.24214/jecet.A.10.3.34751.]

Juurnal of Enviranmental Science, Computer Science and Engineering \& Technology

An International Peer Review E-3 Journal of Sciences and Technology

Available online at www.jecet.org

Section A: Environmental Science

Research Article

\title{
Effects of Organic Amendments (Rice Hull, Cow Owl Sawdust) On Cultivated Corn Production in the University Site "Lwama"
}

\author{
Bilongo Tubemba', Buledi Amuri Lingot ${ }^{2}$, Yuma Brahimu Brakus ${ }^{2}$, Amuri Assani Défi ${ }^{2}$ \\ ${ }^{1}$ Institut Supérieur Pédagogique de Kabambare, Kindu \\ ${ }^{2}$ Université de Kindu / Faculté des Sciences Agronomiques, Kindu
}

Received: 18 May 2021; Revised: 05 July 2021; Accepted: 16 July 2021

\begin{abstract}
A study of the effects of organic amendments (rice husks, sawdust, and cow dung) on the production of corn grown in Lwama I in Kindu in Maniema in the RDC, with the general objective of observing among the organic matter, which could influence maize production in the Lwama I site in Kindu / Maniema / RDC. To achieve this, an experimental set-up in randomized complete blocks comprising four treatments and four repetitions was set up. The results obtained indicated that the maize production was higher for the rice husk treatment, which gave a yield of 3.27 Tons per hectare or $3.270 \mathrm{~kg} /$ Hectare.
\end{abstract}

Keywords: effect, organic amendment, production, corn, Lwama I university site.

\section{INTRODUCTION}

Maniema, an agricultural province, formerly one of the granaries of the Democratic Republic of Congo (DRC) has known for two decades several wars which paralyze all of the activities inherent in the agricultural sector (agriculture, fishing and livestock) ${ }^{[1]}$.Maniema is a Province whose agricultural potential is not to be demonstrated, because the soil, hydrography and climatic diversity offer very favourable conditions for practical agriculture in tropical regions, including the town of Kindu, agriculture is mainly characterized by low yields due to various reasons namely:

- The poor soil;

- Unimproved propagation materials;

- Vulnerabilities to diseases and pests; ( Assistant at ISP Kabambare)

- And the non-existent phytosanitary control etc. 
These low yields therefore create a food shortage which has since grown ${ }^{[2]}$. To increase agricultural production, recourse is had to the increase in sown areas, this poses problems of the availability of land in addition, deforestation due to shifting agriculture affecting the environment and the conservation of natural resources ${ }^{[2]}$.

So, what can be done to increase the production of maize knowing that it is currently the second food crop in the DRC after cassava? However, national production remains insufficient and the country has to import large quantities.

From the above, it is important to know that the cultivation of maize requires the use of organic matter in order to promote the improvement of maize production in the area. Corn is today alongside wheat, one of the main cultivated species in the world. It remains a large traditional food grain in the tropics. It is also cultivated as fodder and the grains are used as feed for livestock and for brewing. This is how the specific objectives based on this research are as follows:

- Identify which organic matter can influence maize production

- Set up an experiment aimed at verifying the effects of organic materials.

\section{MEDIUM, MATERIAL AND METHODS}

Our study was carried out in the Lwama I university site / Lwama district, Mikelenge commune, Kindu city, Chef-lieu of Maniema Province in the DRC. With the following geographical coordinates: the altitude is $497 \mathrm{~m}$, the longitude is $25^{\circ} 65^{\prime}$ 'North and the latitude is $297^{\prime}$ ' south.

The city of Kindu enjoys a climate type AW3 of the KÖPPEN classification with at least three months of dry season which goes from mid-May to mid-August accompanied by fog during the morning and the rainy season, from mid-May to mid-August. August to mid-May with an annual average temperature and precipitation of $1650 \mathrm{~mm}$.

Table 1: Climatic data during the test period

\begin{tabular}{|l|c|l|l|l|c|}
\hline Month & \multicolumn{3}{|c|}{ Température } & \multicolumn{2}{c|}{ Rain fall } \\
\cline { 2 - 6 } & Min & Max & Average & $\begin{array}{l}\text { Rainfall } \\
\text { amount (mm) }\end{array}$ & $\begin{array}{c}\text { Number of } \\
\text { rainy days }\end{array}$ \\
\hline January & 21 & 34,4 & 24,5 & 168,2 & 10 \\
\hline February & 22,6 & 36 & 27 & 131,8 & 12 \\
\hline March & 22,4 & 36,1 & 26,1 & 186,2 & 12 \\
\hline April & 22,8 & 36,3 & 24,1 & 112,5 & 6 \\
\hline
\end{tabular}

Source: Kindu 2017 methodological station. The soil of the experimental site is that of the sandy type. The relief is characterized by the end of the Congolese central basin.

The vegetation of the site is characterized by the strong dense humid dominated by Fagara and Chlorophora excelsa which are the most exploited species. There are also savannas in the surrounding area dominated by Panicum maximum and imperata cylindrica. The species found on our experimental site before it opened are panicum maximum and chromomaena adoratum.

The city of Kindu has a hydrography composed mainly of the Congo River and its tributaries below on both sides of it: 
On the left bank, we have the tributaries: Kindu, Kano, Mikelenge, Lwandoko, Kapondjo. While on the right bank: the Kange, Mesobo, Mangobo, Kabondo rivers.

As plant material, we used the SAMARU variety with the following characteristics:

- Vegetative cycle of 120 days;

- Grain color: yellow;

- Resistance to diseases: fairly low to streak;

- When pouring: good

- Drought: sensitive. ${ }^{[3]}$.

The suitable experimental set-up was that of full blocks randomized with four treatments and four repetitions. The area of the land was $140 \mathrm{~m}^{2}$ due to $14 \mathrm{~m}$ in length and $10 \mathrm{~m}$ in width. The exploited area was $130 \mathrm{~m}^{2}$ made up of 16 plots each of which was $6 \mathrm{~m}^{2}(2 \mathrm{~m} \times 3 \mathrm{~m})$. The paths between the plots, each $6 \mathrm{~m}^{2}$ of which were $25 \mathrm{~cm}$.

\section{CONDUCT OF THE TEST}

Preparation of the ground: The logging clearing took place from December 22, 2016 to January 05, 2017 using a machete. The cleaning on January 08, 2017 using the hoe to rid the ground of stumps accompanied by ploughing on January 20, 2017. At the end, the amendment and the incorporation of organic matter took 14 days before sowing. The sowing was done online, using strings, braid, hoe, stake as well as the seeds, which we sowed on February 11, 2017; at the rate of 2 seeds per pocket with a spacing of $50 \mathrm{~cm} \times 70 \mathrm{~cm}$ and a depth of 2 to $3 \mathrm{~cm}$.

The maintenance consisted of weeding and hoeing. The first weeding was carried out 15 days after sowing, the second weeding 30 days after the first weeding. Threshing, on the other hand, was carried out 45 days after sowing. The hoe was used as the material par excellence to perform all operations. The harvest was manual, ear by ear when the leaves and husks dried out. The harvest was carried out in one day thanks to family labour on May 20, 2017. As for the observations, we analysed the following parameters:

(a) Vegetative parameters:

$>$ Exercise rate in $\%$

$>$ Plant height at 30 days in $\mathrm{m}$ or in $\mathrm{cm}$

$>$ Insertion height of the first ear in $\mathrm{m}$.

\section{(b) Production parameters}

$\checkmark$ Ear length in $\mathrm{cm}$

$\checkmark$ Number of rows per ear

$\checkmark$ Diameter of an ear

$\checkmark$ Weight of 1000 seeds

$\checkmark$ Yield in tonnes / Ha. 
Data Processing: To process the different data collected during our test, we used the variance (AN.VA). To determine which treatment averages differ from each other. We proceeded to the calculation of the smallest significant difference (PPDS) and calculation of variation (C.V).

\section{DISCUSSION OF THE RESULTS}

It emerges from the values recorded in Table 2 that after sowing, the emergence rate was higher for all the treatments. Starting from the other vegetative parameters, it is observed that there is no significant difference between different treatments compared to the smallest significant difference at the 5\% probability level.

Table 2: Effect of organic matter on the growth of the corn crop

\begin{tabular}{|c|c|c|c|c|}
\hline Paramètres & $\begin{array}{c}\text { Average exercice } \\
\text { rate } \mathbf{( \% )}\end{array}$ & $\begin{array}{c}\text { Average plant } \\
\text { height at 30 days } \\
\text { Treatment }\end{array}$ & $\begin{array}{c}\text { Average diameter } \\
\text { of plants at 45 } \\
\text { days } \mathbf{( c m})\end{array}$ & $\begin{array}{l}\text { Insertion point of } \\
\text { the } \mathbf{1}^{\text {st }} \mathbf{\text { ear }}(\mathbf{c m})\end{array}$ \\
\hline $\mathrm{T}_{0}$ & 98,8 & 53,6 & 1,48 & 72,5 \\
\hline $\mathrm{T}_{1}$ & 97,5 & 83,6 & 2,34 & 111,06 \\
\hline $\mathrm{T}_{2}$ & 97,5 & 60,95 & 1,85 & 89,81 \\
\hline $\mathrm{T}_{3}$ & 97,5 & 74,75 & 2,34 & 104,06 \\
\hline $\mathrm{CV}(\%)$ & 1 & 13 & 8,93 & 12,16 \\
\hline Observation & N.S & $*$ & $* *$ & $*$ \\
\hline PPDS & - & 20,13 & 0,40 & 25,9 \\
\hline
\end{tabular}

Legend: T0: Control treatment; T1: Treatment based on rice plowing; T2: Treatment based on sawdust; T3: Treatment based on cow purses; PPdS: Smallest significant difference;C.V: Coefficient of variation; ** : Significant difference; *: Not significant difference.

On the basis of the production parameters (Table 3), the best production performance is observed in the plots where the rice hull-based treatment was applied. This treatment produced a high number of heads per plant, long heads as well as 1000 seed weights greater than other treatments. With this in mind, we say that the results are interesting for the rice husk amendment with 327 grams, which explains the influence of this organic amendment on the growth and production of corn. The production in Tons / Ha has evolved depending on the organic amendments used, the best yield was obtained with the rice husk-based amendment with $3.27 \mathrm{~T} / \mathrm{Ha}$.

Table 3: Effects of organic matter on the production of the corn crop

\begin{tabular}{|c|c|c|c|c|c|}
\hline $\begin{array}{c}\text { Paramètres } \\
\text { Treatment }\end{array}$ & $\begin{array}{c}\text { Head } \\
\text { length }\end{array}$ & Ear diameter & $\begin{array}{c}\text { Number of } \\
\text { rangers per ear }\end{array}$ & $\begin{array}{l}\text { Weight } \\
\text { of 1000 }\end{array}$ & $\begin{array}{l}\text { Yield } \\
\text { T / Hg }\end{array}$ \\
\hline $\mathrm{T}_{0}$ & 14,45 & 6,7 & 15 & 290 & 2,9 \\
\hline $\mathrm{T}_{1}$ & 17,64 & 7,34 & 16 & 327 & 3,27 \\
\hline $\mathrm{T}_{2}$ & 15,73 & 6,93 & 15 & 297,5 & 2,97 \\
\hline $\mathrm{T}_{3}$ & 15,84 & 7,07 & 15 & 313,25 & 3,13 \\
\hline $\mathrm{T}_{4}$ & 15,91 & 2,22 & 15 & 306,93 & 3,06 \\
\hline $\mathrm{CV}(\%)$ & 7,1 & $* *$ & 1,53 & 2,85 & 3,79 \\
\hline Observation & N.S & 0,33 & $* *$ & $*$ & $*$ \\
\hline PPDS & 2,69 & 13,67 & 0,52 & 19,76 & 0,24 \\
\hline
\end{tabular}

Legend: T0: Control treatment; T1: Treatment based on rice plowing; T2: Treatment based on sawdust; T3: Treatment based on cow purses; PPdS: Smallest significant difference; C.V: Coefficient of variation; ** : Significant difference; *: Not significant difference. 
Our results are similar to those of GAY ${ }^{[4]}$ and PATAULE ${ }^{[5]}$. Yield depends primarily on water resources. But also influenced by various genetic, climatic and agronomic factors. In the DRC, the average yield varies from 0.7 to $1.5 \mathrm{~T} / \mathrm{Ha}$, in semi-intensive agriculture, it is 1.5 to $2 \mathrm{~T} / \mathrm{Ha}$.

The results obtained during our research are similar to the results that can be achieved in the DRC if only semi-intensive agriculture were practiced.

\section{CONCLUSION}

The objective of this work was to observe which of the three organic materials could influence the production of corn under the ecological conditions of Kindu. To achieve this, an experimental set-up in randomized complete blocks was set up comprising four treatments and four repetitions. The results obtained showed that the maize yield was higher for the amended plots based on rice husk with $3.27 \mathrm{~T}$ / Ha compared to the almond plots based on cow dung with a production of $3.13 \mathrm{~T} / \mathrm{Ha}$ and then the sawdust-based treatment with $2.97 \mathrm{~T} / \mathrm{Ha}$ and at the end, the control treatment with $2.9 \mathrm{~T} / \mathrm{Ha}$. Besides, we recommend farmers to use rice husk to finally improve the production of corn crop.

\section{REFERENCES}

1. Anonyme, Mémento de l'Agronome, CIRAD (Centre de coopération internationale en recherche agronomique pour le développement), Ministère français des Affaires Etrangères, 2004, 1698 P.

2. M.Mutchapa, Niveau de résistance de trois types de manioc Liyayi, Sawasawa et Butamu à la mosaïque africaine de manioc dans l'hinterland de Kindu, travail de fin d'études.2008, 32 P.

3. Anonyme, 2012 : Mémento de l'Agronome, CIRAD (Centre de coopération internationale en recherche agronomique pour le développement), Ministère français des affaires Etrangères, $1974 \mathrm{p}$.

4. J.P.Gay, Le Maïs mythe et réalité, Atlantica, 1984, 220 P.

5. Pataule Sakina, Influence des plantes de couverture et des herbicides pour la croissance et le rendement de la culture de Maïs à Kindu, travail de fin d'études /F.S.A/UNIKI, Inédit 2017.

\section{* Corresponding Author: Bilongo Tubemba,}

Institut Supérieur Pédagogique de Kabambare, Kindu.

Online date of publication: 18.07.2021 